\title{
Pentahelix Model Collaboration in Tourism Industry Development Policy in Pesawaran Regency
}

\author{
Dian Kagungan ${ }^{1, *}$ Noverman Duadji ${ }^{2,}$ Intan Fitri Meutia ${ }^{3}$ \\ 1,2,3 Public Administration Department, Social and Political Science Faculty, Universitas Lampung \\ *Corresponding author. Email: dian.kagungan@fisip.unila.ac.id
}

\begin{abstract}
The long-term goal of this research is to produce a model Penta helix collaboration in tourism development in the village of Harapan Jaya, Way Ratay District, Pesawaran Regency. The method used in this study is a descriptive method with a qualitative approach, primary data collected through interviews and FGDs. The collaboration of the Penta helix model in tourism development is seen from the parameters of various actors involved.

The results and recommendations of this study are the collaboration of the Pentahelix model in the development of the Harapan Jaya Tourism Village needs particular attention. The lack of communication between actors, the low capacity of funding and management, and the creativity of skilled human resources in manufacturing local tourism industrial products, especially regarding the handicraft and souvenir industry, also affects the level of Penta helix collaboration less than optimal. However, the presence of the tourist village has also brought a positive impact, opening new jobs and preserving the environment with a beautiful area. Therefore, the Pentahelix Model collaboration, with Academics, Private, Community, Government and Media involvement, is crucial to support tourism in the future. However, so far, this collaboration is still not optimal, measured from the interdependence between actors, the unification of ideas as a whole.
\end{abstract}

Keywords: Collaboration, Penta helix model, tourism, Pesawaran.

\section{INTRODUCTION}

Tourism development in Lampung Province is not complete if it goes alone. The Government, tourism business actors, universities, the community and the media must work together so that tourism potential can be exploited to the maximum. The Lampung Province Tourism and Creative Economy Office invite all parties to develop Lampung tourism jointly. The Lampung Provincial Government has formed a cross-sector Coordination Team to develop Lampung tourism. In other words, a collaboration between Penta helix actors in tourism industry development policies in Lampung Province is essential.

The central and local Government's critical role in tourism is based on the idea that the bureaucracy has the power to decide all matters relating to the survival of the people of a country. The bureaucracy also plays an essential role in taking various anticipatory actions to minimize negative impacts, given the many potential problems that arise from tourism.
The role of stakeholders in tourism development also cannot be ignored in Indonesia's tourism development policies through empowerment activities, including the collaborative process of tourism governance in Pesawawan Regency, Lampung Province. The tourism governance process is an adaptive process system and consensus-oriented. Based on two experts, namely: Ansell and Gash, mapped out a collaborative process starting with face-to-face dialogue, building trust, building commitment to the process, sharing understanding, then the formation of an intermediate outcome [1].

The collaboration of the Penta helix model in the development of tourism village tourism is seen from the parameters of the involvement of various actors to work together in optimizing the development of tourist villages. The collaborative process of tourism and tourism management is assumed to occur if several conditions are met (1) There is stakeholder participation. Participation is citizen pow according to Arnstein. (2) There is a condition where there is equality 
of power, meaning no inevitable absolute. Every actor in dialogue is not hindered by hierarchical bound, where there is mutual respect. (3) There are competent actors [2].

The problem formulation of this research is: how is the collaboration between Penta helix actors in the tourism industry development policy in Pesawaran Regency?. The long-term goal of this research is to produce a Penta helix collaboration model in tourism development in the tourist village of Harapan Jaya, Way Ratay District, Pesawaran Regency, which is the location of this research. The benefits of this research are: improving the welfare of local communities in developing the tourism industry in Pesawaran Regency, precisely in Harapan Jaya village, Way Ratay District.

\section{LITERATURE REVIEW}

\subsection{Concept of Tourism Development Policy}

Development activities, including tourism development, will not run well without a good policy in today's modern life. A good policy can be illustrated as a conductor who arranges the game of an orchestra consisting of many musicians with different types of musical instruments, sounds, and time to play them to produce a fantastic song. Thus, every tourism person, and even more so bureaucrats, both within the Government and regional governments, must have a deep understanding of the importance of formulating and implementing sound policies in tourism.

When we talk about tourism development policy, it is necessary to discuss the meaning of "policy" and "development". Judging from practical needs, discussions about theories related to development policies are often not given much attention. People who hear the term "tourism development policy" in general will automatically focus their attention on activities carried out by the Government and local governments in classifying tourism. However, several theories related to the concept in question need to be disclosed in this paper because they help provide a deeper understanding of the activities carried out by the Government and local governments in tourism management.

Meanwhile, in the Merriam-Webster Dictionary, the term "policy", which is translated into Indonesian as "policy", is defined as a rule or idea officially recognized as a guideline for determining the implementation of activities: "an officially accepted set of rules or ideas about what should be done". Thus, the term "policy" or "policy" (especially definition number 2 ) in principle is a parameter that is used as the basis or guideline for carrying out an activity. It is different from the term "policy", which has a more precise meaning. The difference between the two terms is that it is not explicitly explained whether "policy" includes statutory regulations.
Another simple definition of the term is that the direction of action or method of action is chosen from various alternatives by considering the factual conditions, which determine current and future decision making: "A definite course or method of action selected from among alternatives and in the light on given conditions to guide." and determine present and future decisions". Concerning government duties, according to Swanson, understanding of policy in the field of tourism will be easier if it starts from Thomas Dye's definition of "public policy", namely the Government chooses any action to do or not to do that government". Choose to do or not to to" [3].

Meanwhile, the term "development" is defined as a process of change based on a nation's society [4], of course for the better. It is then associated with these two terms, "public policy" and "development policy". It will have the meaning as an officially recognized parameter that is used as a basis or guideline by the GovernmentGovernmentnot do something to realize a change process based on the wishes of the GovernmentGovernment for the better.

In tourism, the term in English is also known, namely "tourism policy". According to McIntodh, GoeldMcIntoshRitchie [5], the term is defined as follows: "Tourism policy can be defined as a set of regulations, rules, guidelines, directives, and development or promotion objectives and strategies that provide a framework within which the collective and individual decisions directly affect long-term tourism development and the daily activities within a destination are taken".

Another opinion Paul S. Biederman also expresses another opinion regarding this term of Travel and Tourism: An Industry Primer, which adds a social aspect to tourism policy: "A tourism policy defines the direction or course of action that is a particular country, region, locality, or a unique destination plans to take when developing or promoting tourism. The key principle for any tourism policy is to ensure that the nation (region or locality) would benefit to the maximum extent possible from tourism's economic and social contributions. The ultimate objective of tourism policy is to improve the progress of the nation (region or locality) and the lives of its citizens" [6].

The two definitions above illustrate that what is meant by tourism policy or what the author translates as "policy in the field of tourism" are various kinds of rules, strategies and targets for tourism development or promotion that become guidelines for decision making in the short and long term. This policy must ensure that the main goal is to make the people concerned who live in tourism destinations obtain optimal benefits from the contribution of tourism in the social and economic fields in the form of progress and quality of life. Suppose it is associated with the concept of development. In that case, it means that the rules, strategies and objectives of the development or promotion of tourism must lead to changes based on the wishes of a nation's people. 
Sustainability. Swanson argues that every government action in the legislative, administrative, and judicial fields affects tourism in tourism. Includes marketing, planning and sustainability activities. According to them, the policy forms are various guidelines (rules), principles and procedures, which are structured ethically and are focused on an issue and represent the expectations of a society (or nation) about aspects of planning, development, products, services, marketing and other aspects of development.

\subsection{Synergy Concept}

Najiyati and Rahmat in Rahmawati define synergy as a combination or combination of elements or parts that can produce better and greater output than before. So synergy can also be understood as a joint operation or a combination of elements to produce a better output. Covey defines synergy as a combination between elements and between parts that will get a better output than before. The indicators in analyzing synergy include effective communication, fast feedback, trust, and creativity between related parties, which are the main requirements for an ideal synergy system [7].

Sofyandi and Garniwa in Rahmawati suggest that synergy can be adequately built in two ways, including:

(1) Source-oriented communication views communication as an activity with a person (source) actual stimuli to respond. Receiveroriented communication is all activities in which a person (receiver) responds to a stimulus or stimulus.

(2) Coordination. Communication cannot stand alone without coordination. In this case, Silalahi in Rahmawati defines coordination as integrating individual activities and units into a joint effort, namely working towards a common goal.

Moekijat in Rahmawatiet states that there are 9 (nine) main requirements in realizing effective coordination, namely:

(1) Direct relationships that will facilitate achievement through direct personal relationships.

(2) Early opportunities in the early stages of planning and policymaking.

(3) Continuity of coordination must take place at all times, starting from the planning stage.

(4) Dynamism, coordination must be continuous

(5) Clear goals to achieve effective coordination.

(6) Simple organization to facilitate effective coordination.

(7) The precise formulation of authority and responsibility will reduce conflict between employees and help work with unity of purpose.

(8) Effective communication

(9) Effective supervisory leadership that will ensure the coordination of activities both at the planning level and at the evaluation level.

Synergy in achieving goals can be achieved through good communication and coordination. The concept of synergy is an effort that must be made to implement Government systems at the central and regional levels.

\subsection{Pentahelix Model Concept}

The Penta helix model was first launched by the Minister of Tourism and Creative Economy then incorporated into the Regulation of the Minister of Tourism of the Republic of Indonesia Number 14 of 2016 concerning Guidelines for Sustainable Tourism Destinations. It ensures the quality of activities, facilities, services and creates experiences and the value of tourism benefits to provide benefits and benefits to the community and the environment. It is necessary to encourage the tourism system by optimizing the role of entrepreneurs, the Government, the community, academics and the media.

Kotler in Saputri state that tourist destinations will gain a competitive advantage if each of the organizations involved can share knowledge, skills, expertise, and other resources that can support the tourism development process. In this case, the Penta helix model focuses on five elements that support the implementation of tourism development. The Government is a policymaker, academics as a transfer of knowledge and related research, the community or community as a social force, entrepreneurs as a force in market mechanisms, and the media to promote tourism objects [8].

\subsection{Pentahelix Actor Role}

The management of the tourism sector cannot be separated from the role of stakeholders in the development process. There are 5 (five) actors who actively contribute to the process of developing the tourism sector, including:

(1) Government

Government in making policy and regulations in the field of tour the tourism development process. In developing the tourism sector, the Government to Government role in providing adequate facilities and infrastructure to support tourism development, preparing policies and regulations relating to the tourism sector, providing adequate facilities, and carrying out promotional and marketing activities for these tourist destinations. The Government to government partnership, a direct role in the development of regulations in tourism, controls the tourism development process and plays a direct role in strengthening institutions to increase capacity and capability in formulating policies or regulations.

(2) Academics

Academics in the tourism development process play a role by conducting scientific studies and various research and community services related to the development of the tourism sector 
in an area. The results of scientific studies and community service conducted by academics can be used to support the success of the tourism sector by collaborating and communicating with academics in the process of developing agrotourism.

(3) Business world

In the tourism development process, the business or private sector plays an essential role in conducting business in the tourism sector that prioritizes business ethics and is professional, responsible, and sustainable. The business world acts as a profit-oriented that will be responsible for environmental sustainability as an essential thing in the tourism sector.

(4) Community

The community in the tourism development process consists of the community and NGOs or NGOs whose role is to support Sapta Pesona by providing tourism services or the creative economy. The community is both an object and a subject in the tourism development process.

(5) Media

The media plays a role in the field of information and tourism promotion. Promotion and marketing in the tourism sector that is inclusive by utilizing social media.

\section{METHOD}

The method used in this study is a descriptive method with a qualitative approach, primary data collected through interviews and FGDs on key informants relevant to this research study. The data were analyzed through the stages of data reduction to concluding. The collaboration of the Penta helix model in the tourism development of the Harapan Jaya tourism village is seen from the parameters of various actors involved. They are working together to optimize the development of the Harapan Jaya tourism village and recreate value for tourism products that illustrate characteristics of the unique products of the agrotourism-based tourism village. The characteristics of the tourism product in question are those related to the potential of the tourism village, including coffee plantations, agriculture and local culinary products (home industry).

\section{RESULTS AND DISCUSSION}

The GovernmentGovernmentbusiness actors, universities, the community and the media must work together so that tourism potential can be exploited to the maximum. The Lampung Province Tourism and Creative Economy Office invite all parties to develop Lampung tourism jointly. The Lampung Provincial Government has formed a cross-sector Coordination
Team to develop Lampung tourism. In other words, the collaboration between Penta helix actors in tourism industry development policies in Lampung Province is critical.

This third-year research took place in Pesawaran Regency, precisely in Harapan Jaya Village, Way Ratay District. The vital role of central and local governments in the tourism sector is based on the idea that the bureaucracy has the power to decide all matters relating to the survival of the people of a country. The bureaucracy also plays an essential role in taking various anticipatory actions to minimize negative impacts, given the many potential problems that arise from tourism.

\subsection{Overview of Way Ratay District, Pesawaran Regency}

Way Ratai District is one of the sub-districts located in the west of Pesawaran Regency and has an average distance of $40.32 \mathrm{~km}$ from the capital of Pesawaran Regency. Geographically, it is located in the south of Lampung Province with some areas in hills, sloping plains, and the coast. Since its inauguration on November 2, 2007, based on Law no. 33 of 2007, Pesawaran Regency has 11 sub-districts and 114 villages.

Pesawaran is the eleventh district in Lampung Province formed in 2007 based on Law no. 33 of 2007. Pesawaran Regency has its capital in Gedong Tataan, $27 \mathrm{~km}$ from Bandar Lampung. Pesawaran has 11 subdistricts and 144 villages. Way Ratai District is one part of the Pesawaran Regency area. Kedondong District, Pesawaran Regency border the north Way Ratai District. The south is bordered by the Gedong subdistrict of the Pesawaran regency. In the east, it is bordered by Padang Cermin District. In the west, it is bordered by Kelumbayan District, Tanggamus Regency. Part of the Way Ratai District is a lowland area, part of it is a hill area with a total sub-district area of $127.21 \mathrm{Km} 2$. Way Ratai District has its capital in Wates Way Ratai Village, which is $41 \mathrm{~km}$ from the capital of Pesawaran Regency. Wates Way Ratai Village has the smallest area of $21.56 \mathrm{~km} 2$.

Way Ratai District is one of the developing areas in the spotlight of the GovernmentGovernmentany Any potential areas can be developed and become regional advantages. Including being a tourist area, an area for agricultural commodities, plantations and freshwater fisheries. Being a new development area has caused RT and hamlets in Way Ratai Sub-district to change so that in 2019 until now, there are 206 RT and 72 hamlets (BPS: Way Ratai Regional Statistics 2020).

Way Ratai sub-district is one of the developing areas in the spotlight of the GovernmentGovernment development area. The RT and hamlets in Way Ratai Sub-district changed from 2014 until now. There were 
206 RTs and 72 Hamlets (BPS: Way Ratai Regional Statistics 2016). Based on its location, Way Ratai District is bordered to the north by Kedondong District, to the south by GedongTataan District, to the west by Kelumbayan District, and in the east by Padang Cermin District (BPS: Administrative Map of Way Ratai District).

Based on its location, Way Ratai District is bordered to the north by Kedondong District, to the south by GedongTataan District, to the west by Kelumbayan District, to the east by Padang Cermin District (BPS: Administrative Map of Way Ratai District). With the area's characteristics, whose morphology is mainly in hills and forest areas, there are still many forest areas and protected forests. The unspoiled forest covers the area borders of that Way Ratai District, namely the Wan Abdurahman Forest Park area.

Way RataiSubdistrict is a self-help village. Harapan Jaya Village which is located close to a protected forest area with an annual rainfall of $\pm 2500-3000 \mathrm{~mm}$, located at an altitude of more than 500 meters above sea level with a hilly topography of slopes dominated by steep slopes so that the development of population settlements has a spread pattern. The area of $\pm 15 \mathrm{~km} 2$ consists of 8 hamlets and 17 houses. Harapan Jaya Village is located quite far from the capital city of Pesawaran Regency $( \pm 70 \mathrm{~km})$ with road access mainly in the form of rocky soil, making this village a little difficult to develop both in terms of social and economic aspects. The number of people living in Harapan Jaya village is moderate, namely 1,520 male residents and 1,325 female residents (BPS Kab. Pesawaran 2020).

Many people in Harapan Jaya Village work in the plantation sector by cultivating land on the hillsides to plant food crops such as corn, sweet potatoes, soybeans, and rice. The planting and tillage system of the people of Harapan Jaya Village is still traditional because the community's education is still at the basic education level, with limited infrastructure and a lack of technical knowledge. From 2015-2020 there was an increase in the number of children attending elementary school $(4.22 \%)$. Still, the number of children attending junior and senior high school decreased by $6.36 \%$ and $2.29 \%$, respectively (CabdinPendidikanKec. Way Ratai).

Administratively, the spatial distribution of Harapan Jaya Village with other areas is:

(1) To the north, it is bordered by: Register 19 Wan Abdul Rahman Forest

(2) In the east, it is bordered by Padang Cermin Village, Padang Cemin District

(3) To the south, it is bordered by Way Urang Village, Hanau Berak Village, PadangCermin District.

(4) In the west it is bordered by Paya Village, Padang Cermin District and Pesawaran
Indah Village, Way Ratai District.

\subsection{Pentahelix Model Collaboration and Harapan Jaya Tourism Village Development}

In the collaboration stage of the Pentahelix Model in the Development of the Harapan Jaya Tourism Village, Way Ratay District, the parameters seen are how the involvement of various actors is to work together in optimizing development in the village. By creating added value product tourist, which describes the uniqueness of the product from the tourist village of Harapan Jaya that distinguishes it from other tourism. The characteristics of the tourism product are related to the village's potential. The management of local handicraft businesses is characteristic of regional culture, waterfall tourist destinations, regional culinary business management, lodging business management, and business management in the form of stalls and restaurants. Shops for necessities for everyday life.

\subsection{Interdependence}

In the development of the Harapan Jaya Tourism Village, Way Ratay District, mutual dependence is a benchmark for seeing the optimal development of the Harapan Jaya Tourism Village, according to Grey in seeing the creation of collaboration, one of which is through the component of interdependence in the world of tourism. Therefore, in this study, the researcher wrote that according to the observations of the Pentahelix Model, Collaboration research in the Harapan Jaya Tourism Village development is still not fully optimized. The theory of interdependence, which according to tourism stakeholders is to foster a sense of dependence between actors, the need for empowerment, especially human resources. The same culture and mindset to understand the Proportionality and Weaknesses of each actor to take part following their respective functions in developing the Harapan Jaya Tourism Village. So far, the community, Governments, communities and media have not existed in the Pentahelix Model Collaboration in the Development of the Harapan Jaya Tourism Village. Therefore, it is necessary to raise awareness among actors because our awareness level in tourism is still deficient, still working with each other. Own (self-help) because according to the recognition of the tourism awareness group to increase interdependence on other actors, it still does not exist because there is no collaboration with related parties. Still, it also does not want dependence on other parties [9].

\subsection{Constructive Unification of Thoughts To Reach Solutions}

Creating collaboration is through the unification of thoughts constructively to equate the vision \& mission and find solutions in development [9]. Therefore collaboration of various components is essential in developing a culture-based tourism village to provide input and ideas for a good mindset. Harapan Jaya 
Tourism Village so far still needs to be considered and requires many ideas and innovations to develop the Harapan Jaya Tourism Village. Therefore there are creative in building a tourist village area.

The results of research observations describe a lack of awareness in collaborating in tourism with other actors. Cooperation in unifying the mindset in developing the tourist village itself is not optimal because there is no shared vision and mission. Therefore participation from other parties will undoubtedly have a positive impact on the development of the Harapan Jaya Tourism Village because the large number of participations will undoubtedly increase the concern for tourism. However, do not forget that there are negative impacts because in collaborating, there is a signature on paper and a moral burden and responsibility and the challenges that will be faced in the future.

\subsection{Joint Ownership of Decisions}

According to (Gray 1989), the third concept is that collaboration is created based on joint decisions between actors in policymaking. In the development of the HHarapanJaya Tourism Village, Way Ratay District, Pesawaran Regency. So far, from the results of research observations carried out in the Harapan Jaya Tourism Village, it has begun to be seen with the Musrenbang in tourism development by inviting leaders, village officials, tourism offices, academics, media, and the private sector as well as other groups involved in the Pentahelix Model Collaboration. However, so far, it is still not optimal in terms of meetings, so decisionmaking is still not based on the mutual agreement because so far, tourism has only been self-supporting, and only a few components are involved.

The lack of communication is the cause of less decision-making with all actors because concern for tourism still needs to be improved. Therefore, the importance of face-to-face meetings and facilitating communication is one of the efforts to establish good relations between components. Furthermore, Harapan Jaya Tourism Village is more focused on deliberation between components and other actors to open informal meetings or formal meeting events as a forum to accommodate input and evaluation to build optimal collaboration. In addition, there must also be the disclosure of information and submitting acceptable and unacceptable inputs.

\subsection{Shared responsibility}

Fourth, according to (Gray, 1989) the concept of collaboration is that tourism is no longer just the responsibility of one party but instead builds a shared responsibility between various parties. From the results of observational research, the concept has been running following field conditions. However, there is still no binding law on the meaning of cooperation (MOU) for the concept of responsibility. So far, only a few parties have collaborated in tourism villages because of the importance of socialization of increasing the number of people participating in the tourist village. According to several stakeholders engaged in tourism so far, there has been no official collaboration. Still, personally, it has always supported the development of the Harapan Jaya Tourism Village for the progress of our Tourism Village. And so far, the professionalism and responsibility of various groups can be seen and proven by so far there is still one vision to introduce Tourism Villages and can still be directed as tourism village work partners. However, it does need a very long process because Harapan Jaya Tourism Village still has work home, to be able to introduce Harapan Jaya Tourism Village and sell unique products that are of public concern.

\section{CONCLUSIONS}

Improving the collaboration of the Pentahelix Model as an optimal development of Harapan Jaya Tourism Village, special attention needs to be paid, due to the low collective awareness of various actors towards neglect, always waiting for directions, and the lack of communication between actors regarding the Harapan Jaya Tourism Village. The low ability of funding and management as well as the creativity of skilled human resources (HR) is to manufacture local tourism industrial products, especially regarding the handicraft and souvenir industry, also affects the level of Penta helix collaboration in the development of the tourism village of Harapan Jaya less than optimal.

However, the presence of a tourist village has also brought a positive impact, such as new jobs and preserving the environment with a traditional cultured area, even though the development of Harapan Jaya Village has not entirely sold as a Tourism destination. Therefore, Pentahelix Model Collaboration, with the involvement of Academics, Private, Community, Government and Media, is crucial for supporting tourism in the future. But so far, the cooperation is still not optimal, measured from the interdependence between actors, constructive unification of thoughts, joint decisions, and shared responsibilities, and only certain parties are involved in the collaboration,

The existence of special regulations as a supporting factor for collaboration Penta helix. Continuous development programs through training are critical, especially concerning fostering the processing and marketing of superior products of local tourist destinations, including budget assistance. Continuous coordination with Penta helix actors in the implementation of various tourism events. 


\section{REFERENCES}

[1] Ansell, Chris, \& Alison Gash. 2007. Collaborative Governance in Theory and Practice, Journal of Public Administration Research and Theory, Vol.18 No.4, Hlm. 543-571.

[2] Collins, Kevin, and Ray Ison. "Jumping off Arnstein's ladder: social learning as a new policy paradigm for climate change adaptation." Environmental Policy and Governance 19.6 (2009): 358-373.

[3] Swanson, Jason R. The tourism policy puzzle: Pieces and precepts discovered through qualitative investigation of federal public policy preferences and advocacy activities of tourism associations in the United States. North Carolina State University, 2010.

[4] Sasmojo, Saswinadi. "Sains, Teknologi, Masyarakat dan Pembangunan." Program Pascasarjana Studi Pembangunan ITB, Bandung (2004).

[5] McIntosh, Robert Woodrow, Charles R. Goeldner, and JR Brent Ritchie. Tourism: principles, practices, philosophies. No. Ed. 7. John Wiley and Sons, 1995.

[6] Biederman, Paul S., and Paul S. Biederman. Travel and tourism: An industry primer. Upper Saddle River, NJ: Pearson/Prentice Hall, 2008.

[7] Rahmawati, Triana. "Sinergitas stakeholders dalam inovasi daerah (Studi pada Program Seminggu di Kota Probolinggo (SEMIPRO))." Jurnal Administrasi Publik 2.4 (2014): 641-647.

[8] Saputri, Riski Andri. Peran Perempuan Muslim Dalam Pengembangan Ekonomi Kreatif Melalui Desa Wisata Colo. Diss. IAIN KUDUS, 2020.

[9] Camelia, D. (2015). Grey systems theory in economics - bibliometric analysis and applications' overview. Grey Systems: Theory and Application,5(2), 244-262. 